\title{
YIELDS AND QUALITY OF PEAS VARIETIES IN LATVIAN AGROCLIMATIC CONDITIONS FOR ORGANIC FARMING
}

\author{
L.Agafonova, J.Vigovskis, A.Švarta \\ "Research Institute of Agriculture", Latvia university of Agriculture \\ “Zemkopības institūts-7”, Skrīveru nov., Latvia, LV 5125 \\ Ph.: +371 5197529, e-mail: ljucerna@inbox.lv
}

\begin{abstract}
Article summarizes results of study detecting the best varieties of peas cultivated in Latvian organic farming conditions. Study was conducted with new varieties of two species of crop peas: Pisum arvense L. (Pink flower varieties) - Retrija, Almara and Vitra, and Pisum sativa L. (White flower varieties) - Lasma and Zaiga. All varieties were selected in Latvia. The best among white flower varieties in terms of crop productivity was Zaiga variety, where yield was 1.45-1.48 $\mathrm{t} \mathrm{ha}^{-1}$. Among pink flower varieties of peas, the most productive was Almara variety, with crop productivity of 1.36-1.69 $\mathrm{tha}^{-1}$. Retrija variety of peas excels other studied varieties by total protein content and taste properties.
\end{abstract}

Keywords: Organic farming, Peas, Protein, Yield.

\section{Introduction}

Human-created artificial agroecosystems proved to be very efficient biologically. They allow providing food for constantly increasing population of the Earth. However, unlike natural systems, they are ecologically unsustainable. In order to maintain ecologically balanced agroecosystem, man must constantly maintain soil fertility, i. e., maintain or increase content of humus and nutrition elements of cultivated crops in soil. The most important peculiarity of organic farming is activation of natural nitrogen-fixing systems, which provide for nutrition of cultivated crops mainly at the account of biological nitrogen.

Pea is one of basic vegetable leguminous crops. Two species of crop peas are cultivated in the Republic of Latvia - Pisum sativa L. (White flower varieties) and P. arvense L. (Pink flower varieties). Ripe peas and unripe seeds as canned or fresh green peas are used in food. Boiled grey peas ( $P$. arvense L.) are Latvian national meal. Therefore Latvian breeders give great consideration to its taste properties. Special value of peas is its high content of protein balanced by amino acid composition. It can successfully replace animal origin protein in human nutrition.

In organic farming, where mineral fertilizers cannot be used, crop peas are very important as soil improverishers. Its role in providing soil with biological nitrogen is especially important. In mineralizing plant residues, it improves also phosphoric nutrition of subsequent crops significantly, and is a good precursor. Therefore, study detecting the best varieties of peas cultivated in organic farming conditions has scientific and practical meaning.

\section{Materials and methods}

Field study was conducted in 2005-2006 on certified organic farming field in Research Institute of Agriculture at LUA. Soil of research field: sod-podzol, loam. Agrochemical properties of topsoil: $\mathrm{pH}-6.2$; humus composition - 2.0-2.4\%; available phosphorus composition - $246 \mathrm{mg} / \mathrm{kg}$ of soil; available potassium composition $-140 \mathrm{mg} / \mathrm{kg}$ of soil.

Study was conducted with new varieties of two species of crop peas: P. arvense L. (Pink flower varieties) - Retrija, Almara and Vitra, and P.sativa L. (White flower varieties) Lasma and Zaiga. All varieties were selected in Latvia. Soil tilth, norms of seeding, terms of planting and harvesting, as well as analyses and degustation were conducted in accordance with VAAD methodology [4]. 


\section{Results and discussion}

Meteorological conditions in years of study were different from average perennial values both by temperature regime and by amount of precipitation, which allowed us to assess studied varieties of peas objectively.

Length of phases of vegetative seasons differed by varieties and changed by years (see Table 1).

Table 1.

Phenological factors of peas in organic farming conditions

\begin{tabular}{|l|l|c|c|c|c|c|}
\hline No & Variety & $\begin{array}{c}\text { Field } \\
\text { germination, }\end{array}$ & $\begin{array}{c}\text { Productive stems } \\
\text { pieces, } \\
\mathbf{n . \mathbf { m } ^ { 2 }}\end{array}$ & $\begin{array}{c}\text { Plant } \\
\text { height, cm }\end{array}$ & $\begin{array}{c}\text { Vegetation } \\
\text { period, days }\end{array}$ & $\begin{array}{c}\text { Lodging, } \\
\text { 1- 9 scale }\end{array}$ \\
\hline \multicolumn{7}{|l|}{} \\
\hline 1 & Zaiga & 72 & 59 & 81 & 79 & 5 \\
\hline 2 & Lasma & 72 & 56 & 86 & 79 & 6 \\
\hline 3 & Retrija & 79 & 71 & 110 & 78 & 3 \\
\hline 4 & Almara & 73 & 56 & 98 & 76 & 3 \\
\hline 5 & Vitra & 75 & 53 & 97 & 81 & 3 \\
\hline \multicolumn{7}{|c|}{$\mathbf{2 0 0 5 .}$} \\
\hline 1 & Zaiga & 93 & 114 & 71 & 71 & 6 \\
\hline 2 & Lasma & 89 & 111 & 74 & 71 & 7 \\
\hline 3 & Retrija & 92 & 108 & 99 & 74 & 4 \\
\hline 4 & Almara & 92 & 121 & 84 & 73 & 4 \\
\hline 5 & Vitra & 92 & 108 & 82 & 76 & 4 \\
\hline
\end{tabular}

From phase ,full shoots" to phase ,full ripening" peas varieties needed 76 to 81 days in 2005 , and just 71 to 76 days in 2006. During sowing in 2005 conditions were cold and humid, shoots showed on the $12^{\text {th }}$ date. Cold and humid spring season of 2005 affected development of peas, which blossomed in the first decade of July only. Accordingly, ripening was delayed, too. The first to ripe was Almara variety (18 August), ripening of other varieties was delayed by 3 to 5 days. During sowing (02.05) in 2006 conditions were dry and warm, but as soon as the second decade of May, precipitations were $156 \%$ of norm, average air temperature was normal. Peas shoots showed on the $7^{\text {th }}$ day. Blossoming began on 24 June. Warm and humid July weather favoured peas development. On 25 August such varieties as Zaiga, Lasma have riped, length of vegetative seasons was 71 days.

Considering conditions of crop cultivation on organic fields, crop production of studied varieties of peas was relatively high (Table 2). The best among white flower varieties by crop productivity was Zaiga variety, where yield was $1.45 \mathrm{t} \mathrm{ha}^{-1}$ in 2005 , and $1.48 \mathrm{t} \mathrm{ha}^{-1}$ in 2006 . The most productive of pink flower varieties was Almara variety. Crop productivity was 1.69 All studied peas varieties had small seeds, but they had higher content $\mathrm{t} \mathrm{ha}^{-1}$ in 2005 , and 1.36 $\mathrm{t} \mathrm{ha}^{-1}$ in 2006. However, by taste properties Retrija variety was noted during degustation (8 points), and high appraisal by this factor also had Lasma variety in 2006. Summer 2006 was dry and hot. All tested varieties of pea had small seeds. While TKW of Almara variety was $204.0 \mathrm{~g}$ in 2005, the same factor in 2006 was the lowest at $154.1 \mathrm{~g}$. Large seeds are peculiarity of Retria variety, where TKW was 380.0 and 306.5 g (in 2005 and 2006, respectively). Similar pattern of TKW factor decrease was also observed with other varieties.of total protein, compared to 2005. The highest content among pink flower varieties had Retrija variety (31.4\%). Average crop productivity, when seeding this variety in demonstration experiments, was $2.5 \mathrm{t} / \mathrm{ha}$, content of total protein $-25.19 \%$. Content of irreplaceable amino acids was 5.58 $\%$, including, lysine $1.36 \%$, tryptophan $0.21 \%$, methionine $0.15 \%$. [1] The highest content of total protein in all years of study among white flower varieties of peas had Zaiga variety and 
was 26.6-26.7\%. However, by taste properties it was worse than Lasma variety. Thus, all studied peas varieties give stable and quality yield in organic farming conditions.

Peas are used both in feed and food. Thanks to its balanced composition, pea protein can replace protein of animal origin in our menu.

Table 2.

Crop productivity and quality of peas seeds in organic farming conditions

\begin{tabular}{|c|c|c|c|c|c|c|}
\hline No & Varieties & Species & $\begin{array}{l}\text { Yield, } \\
\text { t ha }^{-1}\end{array}$ & $\begin{array}{c}\text { TKW, } \\
\text { g }\end{array}$ & $\begin{array}{c}\text { Taste properties } \\
\text { (soaked), } 1 \text { - } 9 \\
\text { scale } \\
\end{array}$ & $\begin{array}{c}\text { Protein } \\
\%\end{array}$ \\
\hline \multicolumn{7}{|c|}{2005.} \\
\hline 1 & Zaiga & Pisum sativum $L$. & 1.45 & 236.8 & 6 & 26.7 \\
\hline 2 & Lasma & P.sativum $L$ & 1.42 & 262.0 & 6 & 25.6 \\
\hline 3 & Retrija & P.arvense $L$ & 1.54 & 380.0 & 8 & 25.8 \\
\hline 4 & Almara & P.arvense $L$ & 1.69 & 204.0 & 6 & 26.5 \\
\hline 5 & Vitra & P.arvense L & 1.59 & 223.7 & 6 & 26.8 \\
\hline \multicolumn{7}{|c|}{2006.} \\
\hline 1 & Zaiga & P. sativum $L$. & 1.49 & 188.3 & 7 & 26.6 \\
\hline 2 & Lasma & P.sativum $L$ & 1.29 & 191.4 & 8 & 25.5 \\
\hline 3 & Retrija & P.arvense $L$ & 1.06 & 306.5 & 8 & 31.4 \\
\hline 4 & Almara & P.arvense $L$ & 1.36 & 154.1 & 7 & 29.0 \\
\hline 5 & Vitra & P.arvense $L$ & 1.25 & 197.9 & 6 & 28.8 \\
\hline \multicolumn{3}{|r|}{$\operatorname{LSD}_{05}(2005)$} & 0.16 & & & \\
\hline & & $\mathrm{LSD}_{05}(2006)$ & 0.13 & & & \\
\hline
\end{tabular}

\section{Conclusions}

1. All studied varieties of peas are suitable for organic farming cultivation in climatic conditions of the Republic of Latvia on sod-podzol sandy-loam soil.

2. The best among white flower varieties by crop productivity was Zaiga variety, where yield was 1.45-1.48 $\mathrm{t} \mathrm{ha}^{-1}$. The most productive among peas pink flower varieties was Almara variety with crop productivity of $1.36-1.69 \mathrm{t} \mathrm{ha}^{-1}$. Retrija variety of peas excels the rest of studied varieties by content of total protein and taste properties.

\section{References}

1. Agafonova L., Jansons A., Rancāne S. Pakšaugu un labību agrofotocenozes izveidošana bioloǵiskas lauksaimniecības apstākḷos // Vide.Tehnoloǵija.Resursi-2009.- 1.sej. 25-27. jūnijs, 107- 112 lpp.

2. Augu šķinnu saimniecisko īpašību novērtēšanas rezultāti 2006.gadā // 2007. - VAAD, Rīga .154-156 lpp.

3. Vigovskis J., Švarta A. Zirņu šķirnes bioloǵiskajā lauksaimniecībā // J.-Saimnieks 2007.-6.sej. -10-15lpp.

4. Valsts Augu Aizsardzības dienests. Pākšaugu šķinnu saimniecisko īpašību novērtēšanas metodika. Pieejams: http://www.vaad.gov.lv/sakums/normatvie-akti.aspx 